\title{
Glomus Tumor of the Buccal Mucosa
}

\section{Bukkal mukozanın Glomus tümörü}

\author{
${\text { Caner Kılıçç }{ }^{1} \text { Pınar Atabey }}^{1}$, Samet Özlügedik ${ }^{1}$, Ümit Tunçel ${ }^{1}$, Nazan Bozdoğan ${ }^{2}$ \\ ${ }^{1}$ Dr.A.Y. Ankara Onkoloji Eğitim ve Araştırma Hastanesi, Kulak Burun Boğaz Kliniği Ankara, Türkiye \\ ${ }^{2}$ Dr.A.Y. Ankara Onkoloji Eğitim ve Araştırma Hastanesi, Patoloji Kliniği Ankara, Türkiye
}

Dergiye Ulaşma Tarihi:17.01.2016 Dergiye Kabul Tarihi:29.02.2016 Doi: 10.5505/aot.2017.66588

\section{ÖZET}

Glomus tümörü, glomus cisminin arteryal segmentinden kaynaklı vasküler bir tümördür. Oral kavite ve bukkal mukozada nadiren görülen bu oluşum benign ve malign mukozalar lezyonlarla karışabilmektedir. Bukkal mukozada beyaz renkli, ağrılı lezyon ile tarafımıza başvuran 54 yaşında erkek hastadan alınan biopsi glomus tümörü olarak raporlandı. Tedavide total kitle eksizyonu bacak cildinden alınan kısmı kalınlıkta cilt grefti ile rekonstrükte edildi. Bir yılık takibinde nüks izlenmedi. Bu lokalizasyonda nadiren görülen glomus tümörü literatür eşliğinde sunuldu.

Anahtar Kelimeler: Bukkal mukoza, Beyaz plak, Glomus tümörü

\begin{abstract}
Glomus tumor is a vascular tumor originating from the arterial segment of the glomus body. This formation is rarely seen in the oral cavity and buccal mucosa and can be mixed with benign and malignant mucosal lesions. Histopathological evaluation of the biopsy taken from a 54 year-old patient who presented with a painful white lesion in the buccal mucosa was reported to be a glomus tumor. For treatment of this tumor, total mass excision was performed and reconstruction was performed with a split-thickness skin graft obtained from the skin of the lower extremity. No recurrence was observed during one year of follow-up. A glomus tumor rarely seen in this localization is presented here in light of literature findings.
\end{abstract}

Keywords: Buccal mucosa, White plaque, Glomus tumor

\section{Introduction}

Oral mucosal lesions are seen histopathologically as lipomatous lesions, salivary gland tumors, hamartomas and neurovascular lesions. Tongue, lip and buccal mucosa are the anatomic localizations that these lesions are most frequently localized (1). It has been reported in many publications that leukoplakia, lichen planus and pemphigus vulgaris schwannoma are among the differential diagnosis when white colored lesions are seen in buccal mucosa. Malignant lesions, especially squamous cell carcinoma may also be mixed up with these lesions with their non-ulcerated image.

Glomus tumor is an arteriovenous anastomosis pathophysiologically and is developed from the body responsible of thermoregulation. Formations not originating from the main vascular structures are seen as round bodies, purple in color and raised from the surface (2). They are seen commonly in the dermis or subcutaneous tissue of the extremities. While they are seen most frequently in the neck in the head and neck region, it may also be seen in the buccal mucosa, although rare (3). Sensitivity to local temperature changes and paroxysmal pain and local tenderness are characteristic properties of these tumors. We planned to present this rarely reported case seen in the buccal mucosa together with a literature search.

\section{Case}

A 54 year-old male patient presented to our clinic with a progressively growing lesion localized at the posterior right buccal mucosa 
for the last 6 months. Upon physical examination, a hyperemic mass, with a white plaque formation, elevated from the surface and painful on palpation was seen (Figure 1). Incisional biopsy was reported histopathologically to be a glomus tumor (Figure 2). Total mass excision was performed for treatment. During the operation, the mass was observed to be invaded to the muscle tissue at the center. The defect performed was reconstructed with a split-thickness skin graft taken from the skin of the leg. Examination at the first postoperative year follow-up revealed no morbidity secondary to the operation or recurrence at the buccal mucosa and the skin of the cheek.

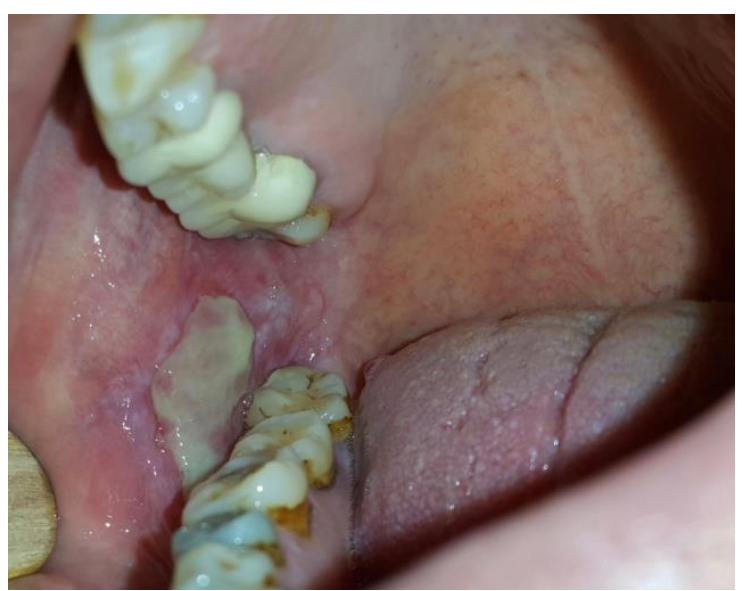

Figure 1: Preoperative mass lesion

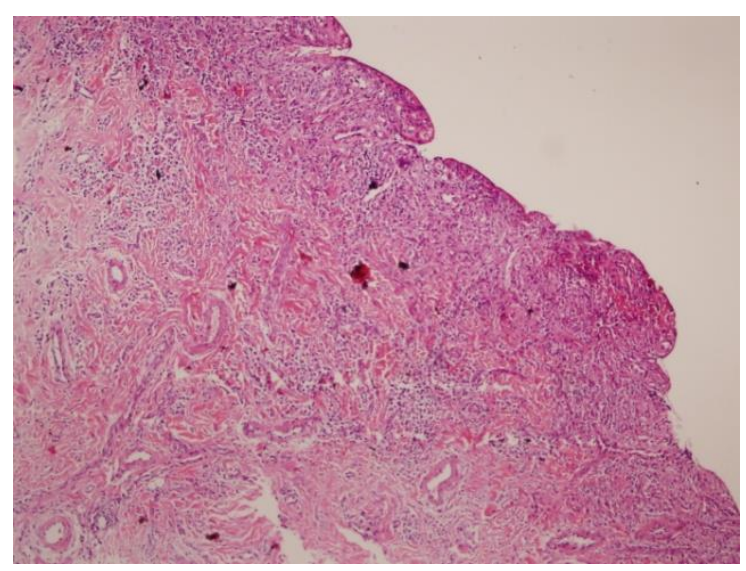

Figure 2: Histopathologically appreance

\section{Discussion}

Glomus body is formed from an arteriovenous shunt responsible of thermoregulation and an arteriole, venules and a sympathetic nerve feeding this shunt. Glomus tumor, on the other hand, originates from the sucquet Hoyer canal of the arterial segment of the glomus body. Although the cause of the proliferation of this angiomatous tissue is unknown, most commonly trauma is accused as the reason (4). They are generally benign tumors; however, Folpe et al reported that benign lesions with a depth of $>2 \mathrm{~cm}$ and a high mitotic activity might demonstrate malignant transformation (5).

Glomus tumor was classified by Esyter and Montgomeryin two types, one of which is characterized with its classical, painful and solitary type and is histologically associated with a blood vessel network and neurofibrills and is capsulated. It is frequently seen in the subungual region; however may be seen in the feet, forearm, bone and oral and nasal cavity, although rare. The second type is the multiple type and is characterized by painless hemangiomas and is non-capsulated and is formed of cavernous vessels histologically (3). Multiple tumors are seen less commonly than the solitary types and are more frequent among males and children (6,7). Solitary lesions are sporadic and multiple lesions demonstrate a dominant trait Solitary lesions are seen as nodular lesions with dimensions starting from a couple of millimeters and reaching to bigger sizes. These nodular lesions, especially the ones located in the nail bed may cause severe pain. The pressure of the vascular net on the sympathetic system has been reported to cause pain (2).

This case presented here was a solitary lesion and there was no family history. These tumors are stained with SMA and vimentin immunohistochemically. This presented case was stained with Fli and CD34 and was vimentin positive.

Painful tumors known as the abbreviation "LEND AN EGG", leiomyoma, eccrine spiradenoma, neuroma, dermatofibroma, angiolipoma, neurilemmoma, endometriosis-cutaneous, glomus tumor and granular cell tumors are among the differential diagnoses of glomus tumors, and especially the ones with a skin involvement. These tumors seen rarely localized at the upper and lower respiratory tract have been defined in many different localizations. Wang et al reported a rarely seen tracheal glomus case with complaints of recurrent cough and dark red bleeding (8). Kessaris et al also reported a 
glomus tumor in the hard palate that can be an example of oral cavity glomus tumors (9). Gaut et al reported a case in the ethmoid roof of the nasal cavity with an extension to the cranial fossa and radiotherapy was used in the treatment of the tumor (10).

Two cases have been reported in buccal mucosa and differential diagnosis includes the frequently seen lichen and pemphigus as well as lymphangioma, a benign hamartomatous lesion originating from lymphatic vesselsto nonulcerated buccal mucosal squamous cell carcinoma (11).

Total surgical excision is recommended in the treatment $(8,9)$. Carbon dioxide laser treatment has been reported to cause more cosmetic results in cutaneous lesions (12). Incomplete resection results in recurrence. We performed a total mass excision and reconstruction with a split-thickness skin graft obtained from the leg. No recurrence was seen during the follow-up period of almost one year and no morbidity secondary to the operation was observed. The diagnosis and treatment of these lesions are important since they recur when excised without an adequate surgical tissue margin and lesions with a longer vertical length might demonstrate malignant transformation. Therefore, it should be considered in the differential diagnosis and delays in the histopathological diagnosis of the buccal mucosal lesions in white color should be prevented.

FINANCIAL DISCLOSURE: We did not receive financial support for this article.

CONFLICT OF INTEREST: In the article, there is no conflict of interest in any.

\section{References}

1. Allon I, Kaplan I, Gal G, Chaushu G, Allon DM. The clinical characteristics of benign oral mucosal tumors. Med Oral Patol Oral Cir Bucal. 2014;19(5):438-43

2. Lever FW, Lever GS. Histopathology of The Skin. Philadelphia: Lippincott Comp, 1983 pp633-636

3. Yu HJ, Kwon SJ, Bahn JY, Park JM, Park YW. Localized multiple glomus tumors of the face and oral mucosa. J Dermatol. 2000;27(3):211-3

4. Chen WC, Lee TS, Ku MC, Hsu KC. Glomus tumors of the upper extremity: Experience with twelve cases. Zhonghua Yi Xue Za Zhi 1995;55(2):163-7

5. Folpe AL, Fanburg-Smith JC, Miettinen M, et al. Atypical and malignant glomus tumors: analysis of 52 cases, with a proposal for the reclassification of glomus tumors. Am J Surg Pathol 2001;25(1):1-12

6. Kohout E, Stout AP. The glomus tumor in children.Cancer. 1961;14:555-66

7. Mackic RM: Glomus tumor in Champion RH, Burton JL, Burns DA, Breathnach SM (eds): Book/ Wilkinson/ Ebling. Textbook of Dermatolgy, Blackwell Science, London, 1998, pp1283-1285

8. Hui Wang, Jun Xie, Yan Tan, Jingting Jiang Glomus tumor of the trachea: a rare case report. Int J Clin Exp Pathol. 2015;8(8): 9723-9726

9. Kessaris $\mathrm{P}^{1}$, Klimis $\mathrm{T}$, Zanakis $\mathrm{S}$. Glomus tumour of the hard palate: case report and review. $\mathrm{Br}$ J Oral Maxillofac Surg. 2001;39(6):478-9.

10. Gaut AW, Jay AP, Robinson RA, Goh JP, Graham SM. Invasive glomus tumor of the nasal cavity. Am J Otolaryngol. 2005;26(3):207-9

11. Allon I, Allon DM, Gal G, Anavi Y, Chaushu G, Kaplan I. Re-evaluation of common paradigms regarding the clinical appearance of oral mucosal malignancies. J Oral Pathol Med. 2013;42(9):670675

12. Padilla RS: glomus tumor in Dermis DJ (ed): Clinical Dermatology, JB lipincott, Philadelphia, 1997 p 7- 69 